\title{
Strategi Pemerintahan dalam Pengembangan Potensi Destinasi Pariwisata di Kabupaten Minahasa
}

\author{
$1^{\text {st }}$ Dr. Abdul R. Dilapanga, \\ M.Si \\ FIS UNIMA \\ Prodi ilmu administrasi negara \\ Tondano, Indonesia \\ abdulrahmandilapanga@unima. \\ $\underline{\text { ac.id }}$ \\ $2^{\text {nd }}$ Jeane Elisabet Langkai \\ FIS UNIMA \\ Prodi ilmu administrasi negara \\ Tondano, Indonesia \\ jeanelangkai@gmail.com \\ $3^{\text {rd }}$ Nikita Tesalonika Rawung \\ FIS UNIMA \\ Prodi ilmu administrasi negara \\ Tondano, Indonesia \\ tessarawung@gmail.com
}

\begin{abstract}
Abstrak- Penelitian ini bertujuan
untuk mendeskripsi strategi pemerintah dalam pengembangan potensi destinasi pariwisata pada Dinas Pariwisata Kabupaten Minahasa dalam mengembangkan potensi wisata di Kabupaten Minahasa. Metode penelitian yang digunakan adalah deskripstif kualitatif, dengan teknik pengumpulan data observasi, wawancara dan dokumentasi. Dari hasil penelitian menunjukan bahwa Dinas Pariwisata Kabupaten Minahasa: 1) belum melakukan analisis tentang kekuatankekuatan potensi destinasi pariwisata, 2). belum melakukan analisis tentang kelemahan-kelemahan dari destinasi pariwasata, 3). belum melakukan analisis tentang peluang-peluang destinasi pariwisata, 4). belum melakukan analisis tentang ancaman-ancaman potensi destinasi pariwisata Untuk itu disarankan agar Dinas Pariwisata
\end{abstract}

Kabupaten Minahasa di Kabupaten Minahasa mengembangkan potensi destinasi pariwisata bersama para ilmuwan dalam bidang manajemen strategi untuk: 1) melakukan analisis tentang kekuatan-kekuatan potensi destinasi pariwisata, 2). melakukan analisis tentang kelemahankelemahan dari destinasi pariwasata, 3). melakukan analisis tentang peluang-peluang destinasi pariwisata, 4). melakukan analisis tentang ancaman-ancaman potensi destinasi pariwisata di Kabupaten Minahasa.

Kata Kunci : Strategi Pemerintah, Pengembangan Potensi Destinasi Pariwisata, Analisis SWOT

\section{PENDAHULUAN}

Sebagai salah satu daerah destinasi wisata, kabupaten Minahasa, memiliki berbagai tempat dan budaya yang dapat dikembangkan, seperti 
wisata alam di dalamnya terdapat wisata alam Bukit Kasih, Danau Tondano, air terjun sonder, wisata sejarah Goa Jepang, Watu pinabetengan, wisata seni dan budaya atau wisata lainnya seperti tarian daerah Kabupaten Minahasa seperti diantaranya tarian Maengket, Cakalele, Kabasaran, Katrili, Kumandong, Lengso. Pariwisata sebagai salah satu sektor yang diharapkan mampu menyerap angkatan kerja dan peningkatan pendapatan masyarakat Minahasa, yang pada gilirannya dapat meningkatkan PAD (Pendapatan Asli Daerah) Minahasa. Penerimaan PAD dari sektor pariwasara belum mencapai target karena masih dalam tahapan pembangunan objek wisata,

Pengembangan Pariwisata di Kabupaten Minahasa dapat membuka lapangan kerja baru bagi masyarakat yang ada di sekitar daerah destinasi pariwisata dikarenakan hal ini dapat menjadi mata pencaharian bagi masyarakat dan dapat meningkatkan perekonomian masyarakat. Masyarakat dapat terlibat dalam jasa transportasi wisatawan maupun penyedia jasa kuliner berupa makanan dan minuman, yang berpotensi meningkatkan kesejahteraan dan perekonomian masyarakat setempat.

Berdasarkan data-data tersebut maka perlu dilakukan pengkajian secara teoritrik dan metodik mengenai strategi pemerintah Kabupaten Minahasa Dalam Pengembangan Destinasi Pariwisata di Kabupaten Minahasa.

Rumusan masalah dalam penelitian ini adalah: Bagaimana strategi Dinas Kebudayaan dan Pariwisata dalam mengambangkan potensi destinasi wisata budaya di Kabupaten Minahasa.

\section{METODE PENELITIAN}

\section{Jenis Penelitian}

Dalam penelitian ini penulis menggunakan metode penelitian kualitatif. Penelitian kualitatif bertujuan untuk mengungkapkan informasi kualitatif sehingga lebih menekankan pada masalah proses dan makna dengan mendeskripsikansesuatu masalah. Penelitian yang dilakukan bersifat Deskriptif yaitu untukmengetahui atau menggambarkan kenyataan dari kejadian yang diteliti [8]. Sehingga memudahkan penulis untuk mendapatkan data yang objektifdalam rangka mengetahui dan memahami strategi pengembanganobjek wisata yang ada di Kab. Minahasa.

\section{HASIL DAN PEMBAHASAN}

\section{Deskripsi Hasil Penelitian}

\section{a. Pelaksanaan Strategi Promosi Wisata}

Kabupaten Minahasa memiliki berbagai obyek wisata yang menarik untuk dikunjungi. Wisata di Minahasa yang sangat beragam adalah salah satu alasan mengapa Kabupaten Minahasa menarik untuk dikunjungi. Kesanekaragaman wisatanya antara lain wisata sejarah, wisata alam, wisata buatan, wisata budaya dan wisata minat khusus. Pemerintah Daerah (Pemda) melalui Dinas Kebudayaan dan Pariwisata Kabupaten Minahasa melakukan berbagai langkah promosi wisata. 
Menurut DN selaku Kepala Bidang Pariwisata saat wawancara pada tanggal 29 November 2018, pihaknya melakukan antara lain: "Strategi promosi yang dilakukan adalah dengan melakukan analisis SWOT terlebih dahulu kemudian menyusun Rencana Strategis dan Rencana Kerja. Selanjutnya kami membagi tugastugas (job description) kepada seluruh pegawai. Hal ini dilaksanakan agar kerjakerja promosi wisata bisa berlangsung optimal."

Dari pendapat di atas diketahui bahwa Kepala Bidang Pariwisata berusaha melakukan perencanaan promosi wisata dengan sangat seksama dan cermat. Hal ini dibuktikan, sebelum melakukan kegiatan promosi pihaknya melakukan analisis SWOT. Dinas Kebudayaan dan Pariwisata Kabupaten Minahasa juga berusaha profesional dalam membagi tugas-tugas (job descrption) promosi wisata ke para pegawai agar promosi dapat berhasil.

Media yang digunakan pada Dinas Kebudayaan, Pariwisata, Pemuda dan Olah Raga Kabupaten Minahasa yaitu sebagai berikut: 1) Media cetak, Media cetak yang digunakan adalah menerbitkan brosur, booklet yang dilengkapi dengan calendar event selama satu tahun, peta wisata serta informasi dari Dinas Kebudayaan, dan pariwisata Kabupaten Minahasa yang disampaikan melalui surat kabar. 2) Media elektronik, Media elektronik yang digunakan adalah telephon, radio dan internet di alamat email www.disbudpar.minahasa.go.id, yang memuat informasi seputar Kabupaten Minahasa secara keseluruhan. 3) Promosi dan pameran wisata, Pameran dan promosi wisata diadakan melalui Pesona Minahasa, yaitu Dinas Kebudayaan dan Pariwisata Kabupaten Minahasa bekerjasama dengan Provinsi Sulawesi Utara.

Berdasarkan pernyataan di atas dapat diketahui bahwa Dinas Kebudayaan dan Pariwisata Kabupaten Minahasa telah melakukan promosi wisata secara modern tidak konvensional. Dinas telah memanfaatkan perkembangan ilmu pengetahuan dan teknologi (IPTEK) dalam mendukung tugas dan fungsinya. Hal tersebut tentu lebih efektif dan efisien dilakukan di era globalisasi seperti sekarang ini.

Pendapat yang hampir sama dikemukakan oleh CB selaku kepala Seksi Objek Wisata Perlengkapan saat wawancara pada tanggal 29 November 2018, beliau mengemukakan antara lain:

"Dalam melaksanakan promosi wisata kami melibatkan semua pihak baik pemerintah, dinas dan masyarakat serta kelompok sadar wisata yang ada di Kabupaten Minahasa. Agar dalam bekerja kita lebih mudah. Hal ini sebagai sebuah konsekwensi dari banyaknya potensi wisata yang dimiliki Kabupaten Minahasa. Kami jujur tidak bisa bekerja sendiri menanganinya."

Dari pendapat di atas diketahui bahwa Dinas Kebudayaan dan Pariwisata Kabupaten Minahasa tidak bekerja sendiri mempromosikan potensi wisata yang ada di Kabupaten Minahasa. Mereka bekerjasama dengan berbagai pihak baik instansi/lembaga pemerintah maupun swasta. Hal 
ini dilakukan karena begitu banyak potensi wisata di Kabupaten Minahasa yang belum dikelola sebagaimana mestinya.

\section{b. Faktor Penghambat Kegiatan Promosi Wisata.}

Anggaran, Salah satu faktor penting dalam terselenggaranya pembangunan adalah besarnya anggaran atau dana yang dimiliki oleh pemerintah. Besar kecilnya anggaran yang dimiliki tentu saja akan mempengaruhi percepatan pembangunan di sektor yang terkait. Pembangunan di sebagian besar negara berkembang di dunia pasti selalu terkendala oleh besaran anggaran yang disediakan pemerintah. Indonesia sebagai negara berkembang tidak lepas dari permasalahan anggaran yang tersedia. Dalam kaitannya dengan pariwisata di Kabupaten Minahasa yang masih berkembang, faktor besarnya anggaran yang tersedia dianggap sebagai salah satu kebutuhan vital demi pertumbuhan pariwisata, seperti dikemukakan oleh informan DS dalam wawancara pada tanggal 17 November 2018. "Ya, kalau untuk mengembangkan pariwisata, anggaran jadi salah satu modal penting, apalagi dengan kondisi pariwisata Kulon Progo yang masih berkembang seperti ini “

Sarana dan Prasarana, Dalam sebuah penyelenggaraan pembangunan, salah satu faktor yang berpengaruh adalah tersedianya sarana dan prasarana pendukung, begitu juga dengan Dinas Kebudayaan Pariwisata Kabupaten Minahasa, tersedianya sarana dan prasarana yang ada tentu saja mempengaruhi proses pelaksanaan programprogram yang akan dilaksanakan. Dinas Kebudayaan dan Pariwisata Kabupaten Minahasa menemukan hambatan dalam hal belum adanya dinas yang khusus mengurusi bidang pariwisata. Hal ini menimbulkan masalah dalam hal koordinasi antar pegawai di Dinas Kebudayaan dan Pariwisata Kabupaten Minahasa.

Kemitraan, Kemitraan dalam konteks pengembangan pariwisata di Kabupaten Minahasa adalah mengenai bagaimana menjalin hubungan, dalam hal ini adalah Dinas Kebudayaan dan Pariwisata Kabupaten Minahasa dengan stakeholder - stakeholder, dan juga masyarakat. Stakeholder disini berupa seluruh pelaku ekonomi yang berhubungan langsung dengan pariwisata di Kabupaten Minahasa.

Partisipasi Masyarakat, Keberhasilan peran pemerintah selanjutnya juga dipengaruhi oleh tingkat partisipasi masyarakat, dalam hal ini adalah seberapa besar kesadaran masyarakat akan pentingnya pariwisata sebagai salah satu sektor yang potensial untuk memajukan ekonomi daerah pada umumnya, dan ekonomi masyarakat lokal itu sendiri. Berdasarkan hasil observasi, mengapa pariwisata Kabupaten Minahasa kurang mampu bersaing dengan Pariwisata di daerah lain salah satunya adalah mengenai kurangnya kesadaran masyarakat terkait dengan pengembangan pariwisata di daerahnya.

Banyak potensi pariwisata lokal di Kabupaten Minahasa yang seharusnya dapat 
menjadi sumber sekaligus penggerak ekonomi masyarakat, namun di sisi lain ternyata jumlah masyarakat yang sadar akan potensi ini masih sangat kurang.

\section{Langkah yang di Tempuh dalam} Mengatasi Hambatan Promosi Wisata. Hambatan-hambatan yang ditemui oleh Dinas Kebudayaan dan Pariwisata Kabupaten Minahasa dalam melakukan kegiatan promosi wisata perlu dicarikan langkah penyelesaiannya agar tidak mengganggu program promosi wisata yang sudah dibuat oleh Dinas Kebudayaan dan Pariwisata Kabupaten Minahasa. Langkah yang ditempuh Dinas Kebudayaan dan Pariwisata Kabupaten Minahasa untuk mengatasi masalah yang muncul dalam kegiatan promosi wisata adalah dengan menjalin kerjasama dengan berbagai pihak yang ada. Mereka duduk bersama mencari solusi penyelesaian. Hal ini terbukti cukup efektif untuk pengembangan potensi destinasi pariwisata di Kabupaten Minahasa.

\section{Pembahasan}

Berdasarkan data yang diperoleh dari lapangan, dapat diketahui strategi promosi wisata Dinas Kebudayaan dan Pariwisata Kabupaten Minahasa. Dalam menentukan strategi promosi yang tepat dalam menarik wisatawan untuk berkunjung ke Kabupaten Minahasa, Dinas Kebudayaan dan Pariwisata Kabupaten Minahasa terlebih dahulu melakukan suatu analisis SWOT, yaitu Strength (kekuatan), Weakness (kelemahan), Opportunities (peluang) dan Threatment (ancaman). Diharapkan Dinas Kebudayaan dan Pariwisata Kabupaten Minahasa mampu menyusun rencana dalam memajukan dan mengembangkan pariwisata secara maksimal. Analisis SWOT difokuskan untuk memprediksi sejauh mana sumber kekuatan dan kelemahan yang dimiliki Kabupaten Minahasa, serta peluang dan ancaman yang timbul bagi pengembangan pariwisata.

Dinas Kebudayaan Pariwisata Pemuda dan Olahraga menghadapi beberapa hambatan dalam pengembangan wisata sebagai berikut

1. Keterbatasan Anggaran

Dengan anggaran yang terbatas, Dinas Kebudayaan dan Pariwisata Kabupaten Minahasa harus dapat melakukan perannya dalam mengembangkan potensi pariwisata secara optimal. Sumber anggaran yang dimiliki oleh Dinas Kebudayaan dan Pariwisata Kabupaten Minahasa seluruhnya berasal dari APBD, sedangkan kondisi APBD daerah Kabupaten Minahsa tidak cukup besar untuk dapat Kabupaten Minahasa adalah mengenai kuantitas sumber daya manusia yang dimiliki oleh Dinas Kebudayaan dan Pariwisata itu sendiri.

2. Partisipasi masyarakat

Dalam pelaksanaan perannya mengembangkan pariwisata, Dinas Kebudayaan dan Pariwisata membutuhkan dukungan penuh dari masyarakat sebagai salah satu pihak yang langsung berhadapan dengan wisatawan di obyek wisata. Berdasarkan penelitian yang telah dilakukan, menunjukkan bahwa sebagian 
masyarakat dinilai belum siap menerima proses pengembangan pariwisata yang dilakukan oleh Dinas Kebudayaan dan Pariwisata.

\section{Belum Maksimalnya Jalinan Kemitraan}

Dalam konsep good governance suatu pembangunan dapat berjalan dengan baik apabila terjadi sinergitas diantara tiga pilar, yaitu pemerintah, swasta dan masyarakat. Belum maksimalnya hubungan dengan pihak ketiga, seperti swasta dan masyarakat membuat peran Dinas Kebudayaan dan Pariwisata dalam mengembangkan potensi pariwisata di Kabupaten MInahasam menjadi terhambat.

Selama ini beberapa hambatan yang dihadapi oleh Dinas Kebudayaan Pariwisata Pemuda dan Olahraga dalam pelaksanaan perannya untuk mengembangkan potensi pariwisata di Kabupaten Minahasa seperti dijelaskan diatas telah diupayakan untuk diatasi dengan cara sebagai berikut :

1. Perencanaan anggaran yang efektif dan efisien

Dalam kaitannya dengan terbatasnya anggaran yang dimiliki oleh Dinas Kebudayaan dan Pariwisata Kabupaten Minahasa, maka diperlukan suatu perencanaan anggaran yang matang sejak awal. Bersamaan dengan perencanaan program yang akan diselenggarakan selama satu tahun, perencanaan anggaran ini sangat penting agar dapat tercapai seluruh program yang telah disusun dapat berjalan dengan baik.

2. Sosialisasi dan Pelatihan
Salah satu faktor yang menjadi penghambat keberhasilan peran yang dilakukan oleh Dinas Kebudayaan Pariwisata Pemuda dan Olahraga dalam mengembangkan potensi pariwisata di Kabupaten Minahasa adalah dalam kurangnya kesadaran wisata masyarakat itu sendiri.

3. Melibatkan masyarakat dalam kegiatan lapangan

Kurangnya jumlah tenaga kerja yang dimiliki oleh Dinas Kebudayaan dan Pariwisata Kabupaten Minahasa tidak dapat dipungkiri sedikit banyak dapat mempengaruhi kinerja. Untuk mengatasi kurangnya personil tenaga kerja, khususnya terkait dengan tenaga kerja yang terjun langsung ke lapangan, maka terkadang dari bagian pengembangan pariwisata melibatkan masyarakat sipil untuk membantu kegiatan-kegiatan tersebut, seperti pelibatan masyarakat di bagian loket pintu masuk obyek wisata, pelibatan masyarakat dalam menyelenggarakan event, dan lain sebagainya.

4. Melakukan promosi baik di dalam maupun di luar wilayah

Dalam rangka menjaring wisatawan dan menarik minat pihak ketiga (investor), Dinas Kebudayaan dan Pariwisata melalui bagian promosi dan pemasaran wisata melakukan promosi secara rutin, baik itu melalui media cetak, maupun dengan jalan mengikuti pameran pariwisata baik di dalam lingkup daerah (provinsi) maupun tingkat nasional. 


\section{PENUTUP}

\section{A. Kesimpulan}

Berdasarkan hasil penelitian, dapat disimpulkan terkait dengan permasalahan mengenai strategi pemerintah dalam mengembangkan potensi destinasi wisata di kabupaten minahasa adalah :

1. Analisis factor internal kekuatan menunjukan pariwisata di Kab Minahasa memiliki potensi alam yang menarik, pantai dan pemandangan alam yang indah, sedangkan kelemahan yang dimiliki, yaitu saran dan prasarana yang belum memadai, kebersihan tempat pariwisata kurang baik, dan sebagian jalan menuju tempat wisata masih rusak belum diperbaiki.

2. Analisis factor kelemahan menunjukan bahwa pariwisata di Kabupaten minahasa belum dikelola dengan baik dapat dilihat dari ketersediaan sarana dan prasarana penunjang serta fasilitas yang belum memadai

3. Analisis factor peluang di kabupaten Minahasa bisa menjadi daerah destinasi pariwisata unggul bertaraf nasional bahkan internasional, mampu mendatangkan investor. Namun dalam kondisi seperti itu juga tidak luput dari berbagai ancaman yaitu kualitas obyek wisata pesaing yang jauh lebih baik dari yang ada di Kabupaten Minahasa.

4. Analisis faktor ancaman menunjukan bahwa terciptanya daerah destinasi pariwisata yang baru di daerah lain dapat menarik wisatawan di Minahasa untuk lebih tertarik untuk berwisata diluar daerah yang akan berpengaruh pada peningkatan jumlah wisatawan di Kabupaten Minahasa.
5. Jadi strategi yang digunakan di pariwisata Kab Minahasa dengan menggunakan strategi SO dan WO dengan melibatkan masyarakat dalam pelaksanaannya baik dalam pemeliharaan lingkungan ataupun kebersihan secara rutin di tempat-tempati wisata yang ada, dengan cara itu pemerintah dapat memberdayakan sumber daya manusia yang ada. Selanjutnya pemerintah membuat event-event budaya dan pariwisata dan festival untuk mendatangkan investor.

\section{B. Saran}

Berdasarkan kesimpulan diatas, peneliti memberikan saran yang terkait dengan strategi pemerintah dalam pengembangan destinasi wisata di Kabupaten Minahasa, Pemerintah sebagiknya melalukan analisis sebagai berikut:

1. melakukan analisis tentang kekuatan-kekuatan potensi destinasi pariwisata,

2. melakukan analisis tentang kelemahankelemahan dari destinasi pariwasata,

3). melakukan analisis tentang peluang-peluang destinasi pariwisata,

4). melakukan analisis tentang ancaman-ancaman potensi destinasi pariwisata di Kabupaten Minahasa.

\section{UCAPAN TERIMA KASIH}

Terimakasih disampaikan kepada semua pihak yang boleh membanti dalam pelaksaan penelitian sehingga artikel ini dapat diselesaikan. 


\section{REFERENSI}

[1] Sudarwan dan Yunan Danim (2010: 18). Ilmu Pariwisata Sebuah Pengantar Perdana. Jakarta: PT. Pradnya Paramita.

[2] Ulber

Silalahi

(2002:

4).

MetodePenelitianSosial. Jakarta: Refika Aditma

[3] Stoner, Freeman, dan Gilbert. Jr. 2001. "Manajemen Strategi, Edisi Imdonesia". Jakarta: Gramedia

[4] Heene. Aime. 2010. Manajemen Strategik Keorganisasian Publik. Bandung: PT. Refika Aditama.
[5] David Guswan, 2015.Strategi Pengembangan Pariwisata

[6] Pearce II, John A. dan Robinson Richard B.Jr. (2008). Manajemen Strategis 10. Salemba Empat : Jakarta

[7] Nyoman.S. Pendit. 2002. Ilmu Pariwisata Sebuah Pengantar Perdana. Jakarta : Pradya Paramita

Sugiyono, 2009, Metode Penelitian Kuantitatif, Kualitatif dan R\&D, Bandung : Alfabeta 